\title{
Management of superficial straw associate with strategy of physical improvement of the soil in the emergence of weeds
}

\author{
David Peres da Rosa $^{1 *}{ }^{\oplus}$, Anderson Luis Nunes ${ }^{1} \oplus$, Alisson Alves ${ }^{1} \oplus$, Marcos Longaretti ${ }^{1} \oplus$ \\ ${ }^{1}$ Instituto Federal de Educação, Ciência e Tecnologia do Rio Grande do Sul, Sertão, RS, Brasil. E-mail: david.darosa@sertao.ifrs.edu.br; anderson.nunes@sertao.ifrs.edu.br; \\ alisson.alvesagro@gmail.com; marcos.longaretti@hotmail.com
}

ABSTRACT: The objective of this work was to qualify the improvement of the physical properties of the soil and the reduction of weeds by combining the management of the superficial cover associated with a strategy of physical improvement soil in the drilling, seeking the maintenance of the no-tillage system. The experiment was carried out in the 2015/16 and 2017/18 harvests, using a randomized block design in a two-factorial scheme $(32)$ with three managements of the ground cover (chopped, rolled and natural) and two depths of planter's shank (7 and $12 \mathrm{~cm}$ ). Counts and identification of weeds emerged in the row and between the lines of the soybean crop at 20 and 40 days after emergence, bulk density, mechanical resistance of the soil to penetration and total soil porosity in the flowering of the soybean culture were measured. The management of the straw cover combined with the depth of action of the planter shank influenced the emergence of weeds, as well as, the increase in the depth of the furrow improvement of the physical environment of the soil in the sowing line, reducing penetration resistance, bulk density and increasing total porosity.

Key words: fertilizer shank; seeder; soil compaction; straw; total porosity

\section{Manejo da palha associada a estratégia de melhoria física do solo na emergência de plantas daninhas}

RESUMO: O objetivo desse trabalho foi qualificar a melhoria das propriedades físicas do solo e a redução de plantas daninhas pela combinação do manejo da cobertura superficial, associada a uma estratégia de melhoria física do solo na semeadura buscando a manutenção do sistema plantio direto. 0 experimento foi realizado nas safras 2015/16 e 2017/18, utilizando o delineamento experimental de blocos ao acaso em esquema bi-fatorial $(3 \times 2)$ com três manejos da cobertura solo (triturada, rolada e natural) e duas profundidades de atuação da haste sulcadora da semeadora ( 7 e $12 \mathrm{~cm})$. Foram quantificados: contagens e identificação de plantas daninhas emergidas na linha e entrelinha da cultura da soja aos 20 e 40 dias após emergência, avaliação da densidade do solo, resistência mecânica do solo a penetração e porosidade total do solo no florescimento da cultura da soja. $O$ manejo da cobertura da palha combinado com a profundidade de atuação da haste sulcadora influenciaram na emergência das plantas daninhas, bem como, o aumento da profundidade da haste sulcadora na semeadura resultou nas maiores produtividades da cultura da soja, e na melhoria do ambiente físico do solo na linha de semeadura, reduzindo a resistência da penetração, densidade do solo e aumentando a porosidade total.

Palavras-chave: sulcador; semeadura; compactação do solo; palha; porosidade total

\footnotetext{
* David Peres da Rosa - E-mail: david.darosa@sertao.ifrs.edu.br (Corresponding author)

Associate Editor: Mário de Andrade Lira Júnior
} 


\section{Introduction}

The no-till farming system (NTS) occupies a large part of the Brazilian agricultural soils, having countless advantages. Some of these are the following: reduction of soil temperature oscillation that keeps the soil biodiversity preserved; decomposition of crop residues, providing increased soil fertility; and presence of vegetation cover, reducing the erosive processes. One of the pillars of this production system is the permanent soil covering, hailing from the remains of the previous crop (Karayel \& Šarauskiset, 2019).

Besides the benefits related to the soil, this production system provides a reduced seed germination in photoblastic positive weeds (Silva et al., 2016). These advantages, when in association, result in increased crop yield and system sustainability (Qiu \& Wang, 2018; Karayel \& Šarauskiset, 2019). In a maize crop under NTS, the cover management prior to the sowing reduced weed infestation in accordance to the straw (Favarato et al., 2014). Rolling the black oat cover was more efficient, compared to non-rolling it, in suppressing the "capim-papauã" or plantain signal grass (Urochloa plantaginea) (Silva et al., 2016).

Not inverting the soil, another indispensable point in the NTS, has been causing problems regarding compaction of the soil physical structure. This occurs mainly due to intense agricultural machinery traffic, lack of crop rotation and execution of management practices, with the soil being above the friability point and close to its plastic limit (Botta et al., 2016). Among the decompaction forms employed is the use of subsoilers and/or scarifiers, implements capable of breaking compacted soil layers in the subsurface. However, its effects tend to disappear in up to 24 months (Drescher et al., 2016; Milagres et al., 2018).

Another feasible way in mitigating the compaction effects is by increasing the action depth of the fertilizer shanks during the sowing (Rosa et al., 2015). This allows reducing the compaction in the first $15 \mathrm{~cm}$ of depth while keeping the premise of not inverting the soil (Trentin, 2015; Drescher et al., 2016; Sivarajan et al., 2018). However, the studies relating the effects on both physical properties and weed population dynamics are still scarce. Therefore, the objective of this study was to qualify the efficiency of the surface cover management associated with a strategy of physically improving the soil at sowing, both on enhancing the soil physical properties and on the weed emergence, seeking to keep of the no-till system.

\section{Materials and Methods}

The experiment was conducted in a Red Nitisol (Embrapa, 2018) under the no-till farming system for over 16 years, located in the agricultural production area of the Federal Institute of Education, Science and Technology of Rio Grande do Sul-Sertão Campus, in the municipality of Sertão - RS. This research was conducted in two agricultural years, 2015/2016 and $2017 / 2018$, with the soybean crop (Glycine max L.) sown on 22/11/2015 and 30/11/2017 under white oat (Avena sativa L.) cover having the dry weight of 6.7 and $5.3 \mathrm{Mg} \mathrm{ha}^{-1}$, respectively.

Treatments were distributed in a randomized block experimental design with a two-factor design. Factor " $A$ " corresponded to the straw cover managements: chopped, rolled and natural (not managed). Factor " $B$ " corresponded to the depth of the fertilizer shank: 7 (control) and $12 \mathrm{~cm}$ (physical improvement strategy). Four replicates were used with plots of $4.2 \times 7.0 \mathrm{~m}$, with $5.0 \mathrm{~m}$ between plots and $0.5 \mathrm{~m}$ between blocks.

Cover crops were desiccated with glyphosate (720 g a.i. $\mathrm{ha}^{-1}$ ) during the pre-sowing of the soybean crop. In factor " $A$ ", the mechanical straw management was performed two days prior to the sowing, with a straw chopper from the Jan brand, model Tritton 2300, used to manage the chopped straw cover. As for the rolled straw cover, a hydraulic dump box was coupled to the tractor, driven close to the ground in order to promote a plant tumbling action. The crop was implemented by using a Semeato ${ }^{\circ}$ multiple seeder, model SHM 15/17 with 7 rows spaced $0.45 \mathrm{~m}$ apart and equipped with guillotine-type fertilizer shanks, noting that all fertilization cultural traits and phytosanitary applications were the same for all treatments.

The determination of the soil physical state was during the soybean crop flowering, period of the greatest plant intake in relation to the soil physical state, as well as 2 months after implementing the physical treatments. Data were collected on the soil mechanical resistance to penetration (PR), bulk density (BD) and total porosity (TP). PR was measured in transect to the sowing row to later provide the isolines map of this parameter. To this end, the measurement was taken at the sowing row and three more points equidistant to its right and left, with spacing of $0.05 \mathrm{~m}$ and measurement depth of $0.3 \mathrm{~m}$. A digital penetrometer, the Penetrolog from Falker ${ }^{\circ}$ brand, was employed at field capacity condition (gravimetric moisture was $0.312 \mathrm{~g} \mathrm{~g}^{-1}$ in 2015/2016 and $0.308 \mathrm{~g} \mathrm{~g}^{-1}$ in 2017/2018). SD and TP were performed according to the methodology proposed by Embrapa (2017), by collecting soil in a structure preserved in stainless steel cylinders $(0.05 \times 0.05$ $\mathrm{m}$ ) on the rows and inter-rows at the depths from 0.02 to 0.07 $\mathrm{m}, 0.07$ to $0.12 \mathrm{~m}$, and 0.12 to $0.17 \mathrm{~m}$, to evaluate the effect of mobilizations performed during physical treatments.

Crop yield was measured by cutting and trailing plants arranged in $2.0 \mathrm{~m}^{2}$ of the plot, performed on the central rows, with the yield being adjusted to $13 \%$ grain humidity. The evaluation of weed incidence was by counting the number of emerged weeds at two different moments: at 20 and at 40 days after sowing (DAS). Countings were performed in the rows and inter-rows, trying to verify the mobilization influence of the fertilizer shank in this parameter. To this end, this procedure was performed in an area of $4.0 \times 0.1 \mathrm{~m}$, with this location fixed for evaluation at the two moments of analysis. After each counting, weeds were controlled with glyphosate (720 g a.i. ha-1).

A joint analysis of experiments was conducted in order to determine the effect of the season on the analyzed variables (Banzato \& Kronka, 2006). The analysis of variance and 
comparison of means by the Tukey test were performed using the Sisvar 5.6 software. The Surfer $14^{\circ}$ software was also used to prepare the isoline maps of the $P R$, through the kriging interpolating method.

\section{Results and Discussion}

The joint analysis of experiments revealed the mean square of the isolated experiments (2015/16 and 2017/18 crops) demonstrated a ratio greater than 7:1. Therefore, the experiments must be presented individually (Banzato \& Kronka, 2006). Moreover, during the two seasons that the experiments were conducted in, SD and TP did not differ along the soil profile starting from 0.07 to $0.17 \mathrm{~m}$ (data not presented). Thereby, only the data starting from the 0.02 to $0.07 \mathrm{~m}$ layer will be presented (Table 1 ) for characterizing the soil physical structure, superficially, and to establish relations with the weed emergence and the soil physical condition. Combined to this is the fact weed seeds in the soil are mainly concentrated in its superficial layer when under the no-till system (Silva et al., 2016). The non-significance of SD and TP along the soil profile is probably related to the absence of changes in these physical parameters, indicating that the mobilization by the shanks did not change such properties and there are no physical problems in the area. This condition was also found when comparing the NTS with a scarified soil (Calonego et al., 2017) and when comparing the NTS with a scarified + harrowed soil (Cherubin et al., 2015).

Table 1. Bulk density (BD) and total porosity (TP) of the soil in the layer from 0.02 to $0.07 \mathrm{~m}$ under different straw management, action depths of the seeder shank (NTS7 and NTS12), collection location and F test in 2015/2016 and 2017/2018 crops.

\begin{tabular}{|c|c|c|c|c|}
\hline \multirow{2}{*}{$\begin{array}{c}\text { Physical } \\
\text { management (PM) }\end{array}$} & \multicolumn{2}{|c|}{$2015 / 2016$} & \multicolumn{2}{|c|}{$2017 / 2018$} \\
\hline & $\begin{array}{c}\mathrm{BD} \\
\left(\mathrm{Mg} \mathrm{m}^{-3}\right)\end{array}$ & $\begin{array}{l}\text { TP } \\
\text { (\%) }\end{array}$ & $\begin{array}{c}\text { BD } \\
\left(\mathrm{Mg} \mathrm{m}^{-3}\right)\end{array}$ & $\begin{array}{l}\text { TP } \\
\text { (\%) }\end{array}$ \\
\hline NTS7 $^{1}$ & $1.24 \mathrm{a}^{*}$ & $46.63 \mathrm{a}$ & $1.28 \mathrm{a}$ & $54.26 \mathrm{~b}$ \\
\hline NTS12 & $1.22 \mathrm{~b}$ & $46.30 \mathrm{a}$ & $1.24 \mathrm{a}$ & $57.33 \mathrm{a}$ \\
\hline \multicolumn{5}{|l|}{$\begin{array}{c}\text { Straw } \\
\text { management (SM) }\end{array}$} \\
\hline Chopped & $1.26 \mathrm{a}$ & $43.00 \mathrm{~b}$ & $1.26 \mathrm{a}$ & $55.90 a b$ \\
\hline Rolled & $1.22 \mathrm{~b}$ & $48.10 \mathrm{a}$ & $1.30 \mathrm{a}$ & $53.94 b$ \\
\hline Natural & $1.22 b$ & $48.20 \mathrm{a}$ & $1.24 \mathrm{a}$ & $57.54 \mathrm{a}$ \\
\hline \multicolumn{5}{|l|}{ Location (L) } \\
\hline Row & $1.17 \mathrm{~b}$ & $49.40 \mathrm{a}$ & $1.22 b$ & $57.25 \mathrm{a}$ \\
\hline Inter-row & $1.30 \mathrm{a}$ & $43.50 \mathrm{~b}$ & $1.30 \mathrm{a}$ & $54.34 b$ \\
\hline \multicolumn{5}{|l|}{ F Test } \\
\hline PM & * & ns & ns & $*$ \\
\hline SM & * & $*$ & ns & $*$ \\
\hline $\mathrm{L}$ & $*$ & $*$ & $*$ & $*$ \\
\hline $\mathrm{PM} \times \mathrm{SM}$ & $*$ & ns & ns & ns \\
\hline$P M \times L$ & ns & ns & ns & ns \\
\hline SM $\times \mathrm{L}$ & ns & ns & ns & ns \\
\hline$P M \times S M \times L$ & ns & ns & ns & ns \\
\hline CV (\%) & 6.98 & 7.90 & 3.38 & 3.44 \\
\hline
\end{tabular}

*Means followed by the same letter did not differ from each other by Tukey test $(p \geq 0.05)$ 1 NTS7: No-till system with fertilizer shank acting at $7 \mathrm{~cm}$; NTS12: No-till system with fertilizer shank acting at $12 \mathrm{~cm}$; CV: Coefficient of variation
In 2015/16 crop under NTS12, the SD (1.22 $\mathrm{Mg} \mathrm{m}^{-3}$ ) differed from NTS7 (1.24 $\left.\mathrm{Mg} \mathrm{m}^{-3}\right)$, indicating lower density when using the fertilizer shank at greater depths. However, this parameter had significant interaction between straw and physical managements and thus it is displayed in Table 2 . In the collection position, there was a difference in both evaluated years, with the shank effect in the sowing row, in this case, being independent of its working depth, decreasing the SD and increasing the TP, hence providing improvement for the soil physical state. Using a fertilizer shank at greater depths, when establishing the maize crop, provided a greater SD reduction and TP increase in the sowing row, being able to even break the compacted soil layer (from 0.07 to $0.15 \mathrm{~m}$ ), resulting in improved root development (Drescher et al., 2017).

Analysis of variance was significant in the straw management in the two variables analyzed during the year 2015/2016, and in the year 2017/2018 it had an effect on porosity. In the first year, the chopped cover had higher SD and lower TP when compared to the rolled and natural straws; yet during the second year, the natural condition (57.54\%) differed from the rolled one (53.94\%), which was the lowest. Chopping the cover increases the decomposition speed and consequently decreases the buffering effect of the stresses generated by traffic on the soil (Castioni et al., 2019). Thus, it provides greater susceptibility to soil compaction as well as greater exposure to impact of drops, which generates greater particle disaggregation, clogging the macro-pores and resulting in the reduced water infiltration into soil. This transforming action of the plant in small proportions may be corroborating the SD increase that occurred during the first year.

Total soil porosity, a parameter that demonstrates the porous space of the soil structure, was not influenced by the shank action (Table 1). However, during the second year, total porosity was higher with the shank at the greatest depth. In Red Oxisol, changes in the soil pore space occurred with the reduction in microporosity and the increase in macroporosity when using the fertilizer shank at greater depths during the sowing (Drescher et al., 2016).

In these determinations, the interaction between the factors was not significant with the exception of SD during the first year, when there was a combination effect between physical and straw managements (Table 2). There, the furrower at greater depth, regardless of straw management, provided a SD reduction.

Soil mechanical resistance to penetration (PR), which provides the resistance the roots have to develop, reached up to 3.4 MPa during the first year (Figure 1) and 2.2 MPa in the

Table 2. Bulk density in the interaction of physical and straw managements during 2015/2016.

\begin{tabular}{ccccc}
\hline $\begin{array}{c}\text { Straw/physical } \\
\text { management }\end{array}$ & \multicolumn{2}{c}{ NTS7 $^{1}$} & \multicolumn{2}{c}{ NTS12 } \\
\hline Chopped & 1.27 & $\mathrm{~A}$ & 1.25 & $\mathrm{~B}$ \\
Rolled & 1.23 & $\mathrm{~A}$ & 1.21 & $\mathrm{~B}$ \\
Natural & 1.23 & $\mathrm{~A}$ & 1.21 & $\mathrm{~B}$ \\
\hline
\end{tabular}

*Means followed by the same uppercase letter did not differ from each other by Tukey test $(p \geq 0.05)$

${ }^{1}$ NTS7: No-till system with fertilizer shank acting at $7 \mathrm{~cm}$ and at $12 \mathrm{~cm}$ (NTS). 

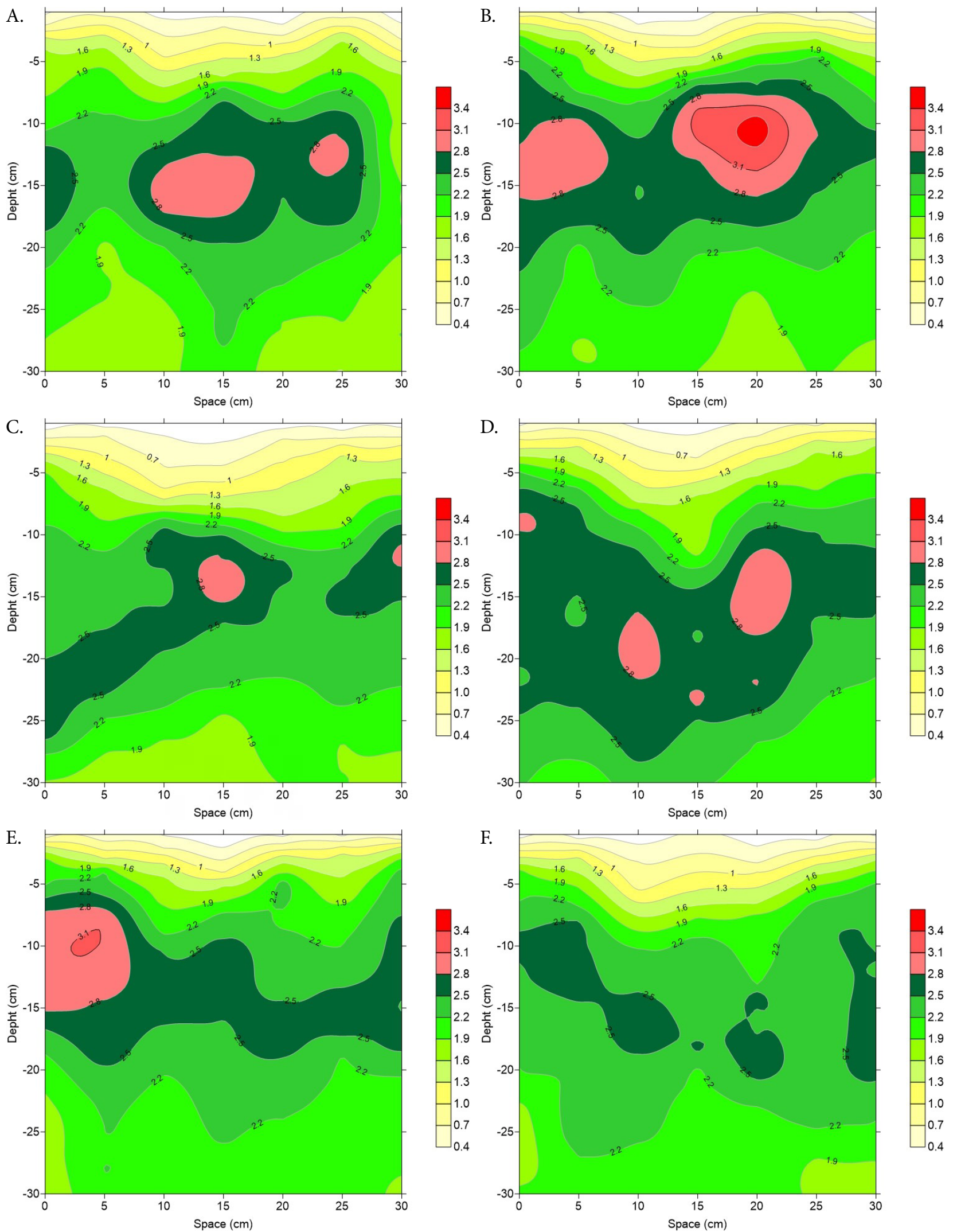

NTS7: No-till system with fertilizer shank acting at $7 \mathrm{~cm}$; NTS12: No-till system with fertilizer shank acting at $12 \mathrm{~cm}$.

Figure 1. Isolines maps of the soil mechanical resistance to penetration (MPa) for 2015/2016. A. Chopped straw in NTS7 and B. NTS12; C. Rolled straw in NTS7 and D. in NTS12; E. No straw management, natural in NTS7 and F. NTS12.

second year (Figure 2) in this study. Values below 2.5 MPa do not have any limitations for root growth; values between 2.6 and $10 \mathrm{MPa}$ have some limitations, but when above $10.1 \mathrm{MPa}$ the root growth is impossible (Reichert et al., 2008). In the treatments under NTS12 (Figure 1B, D and F), having some of the 2.5 MPa restriction as reference, the values appear only 
A.
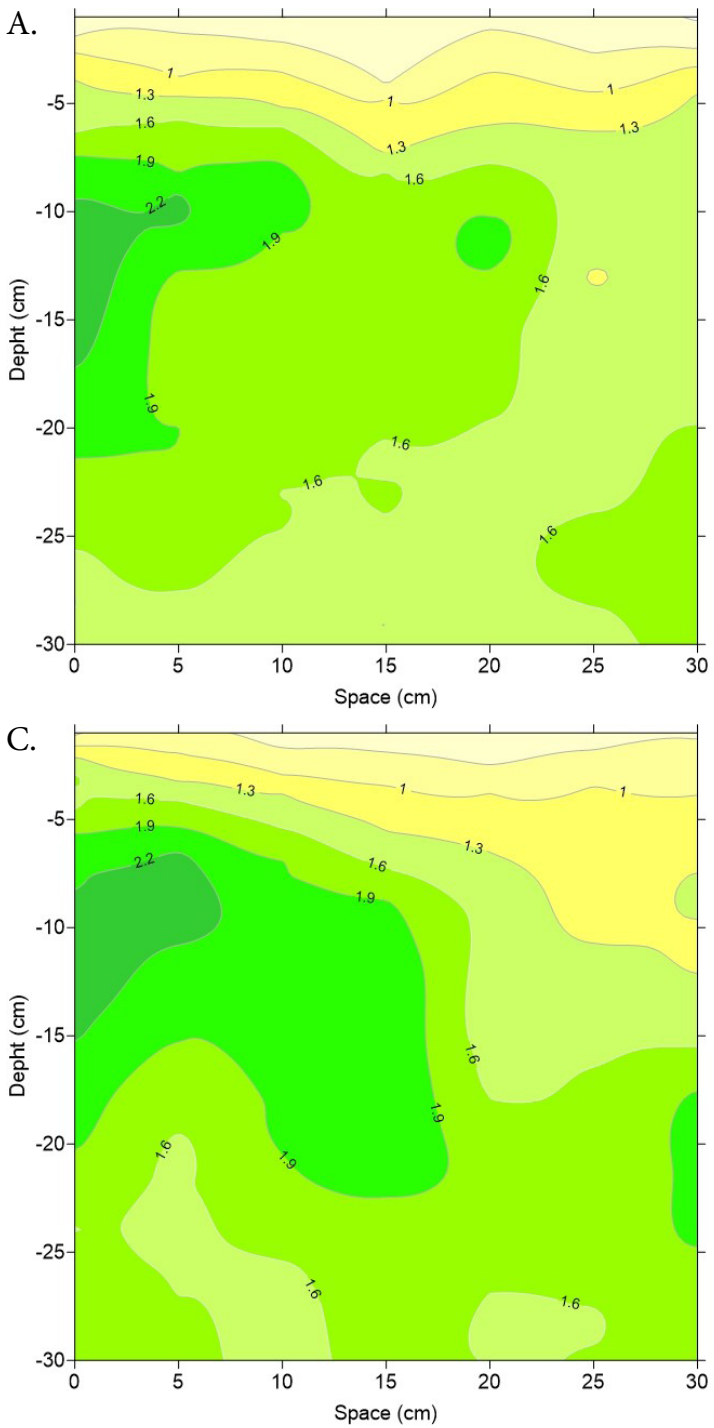

E.

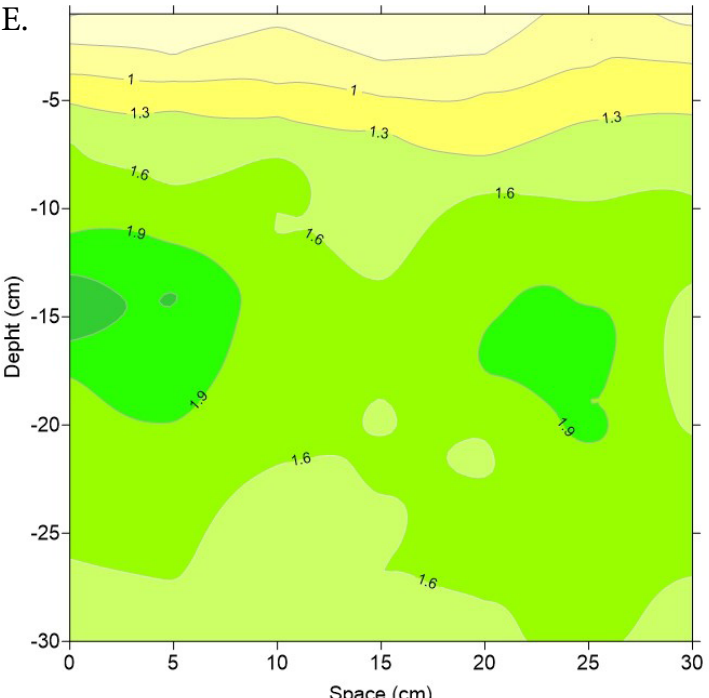

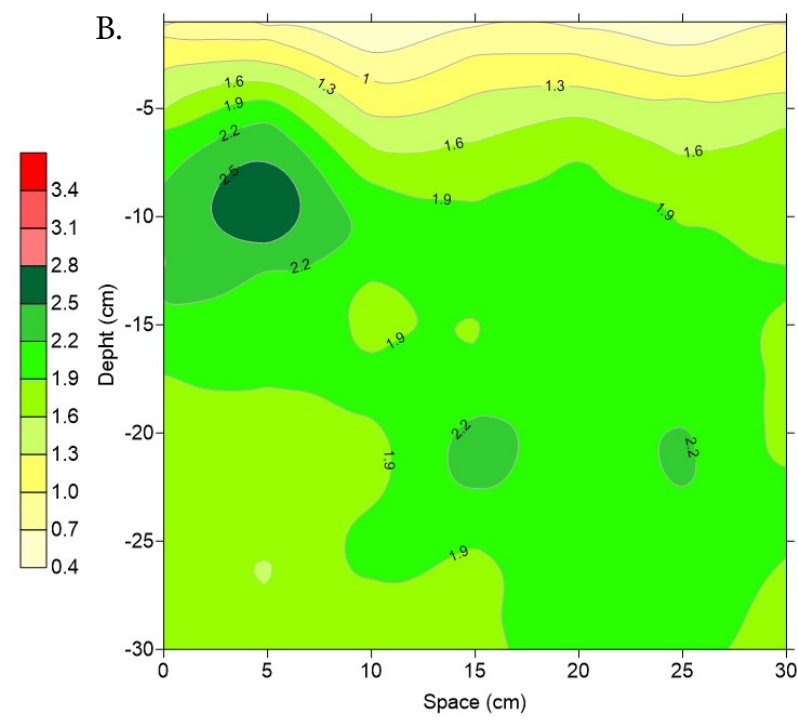
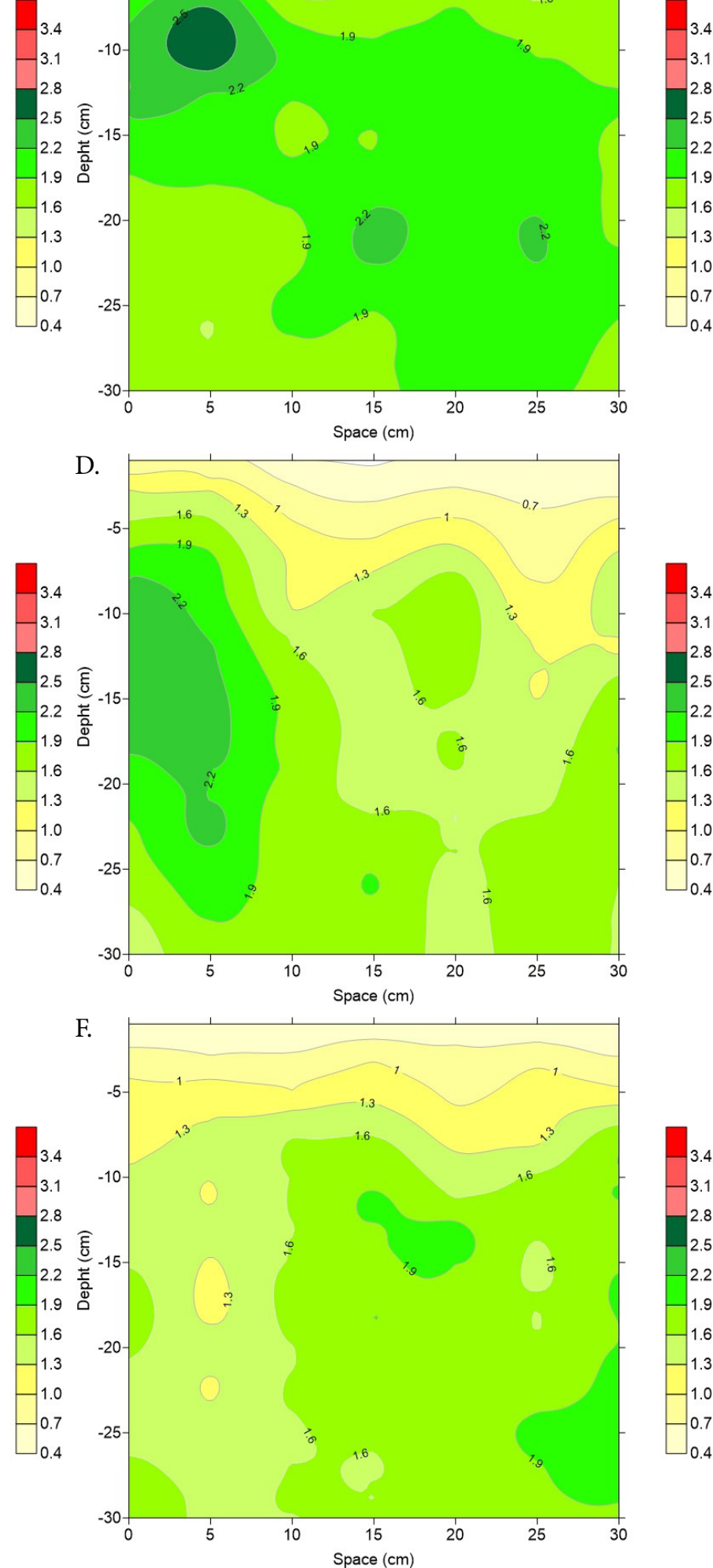

${ }^{1} \mathrm{NTS7}$ : No-till system with fertilizer shank acting at $7 \mathrm{~cm}$; NTS12: No-till system with fertilizer shank acting at $12 \mathrm{~cm}$

Figure 2. Isoline maps of the soil mechanical resistance to penetration (MPa) for 2017/2018. A. Chopped straw in NTS7 ${ }^{1}$ and B. NTS12; C. Rolled straw in NTS7 and D. in NTS12; E. No straw management, natural in NTS7 and F. NTS12.

below the $12 \mathrm{~cm}$ depth. However, when under NTS7 (Figure $1 \mathrm{~A}, \mathrm{C}$ and $\mathrm{E})$ they are just before or near the $10 \mathrm{~cm}$ depth in the sowing line, emphasizing the effect of deepening the seeder shank on the soil physical improvement, thus corroborating Rosa et al. (2015), where this management reduced the soil mechanical resistance. 
The largest area with restrictive PR was in the chopped management, covering a range of 7 to $18 \mathrm{~cm}$ in NTS12 (Figure $1 B)$, with the shank effect in the sowing row visible in this treatment, generating a reduction to up to $2.0 \mathrm{MPa}$. This fact combined with higher density (1.25 $\mathrm{Mg} \mathrm{m}^{-3}$ ) (Table 2) and lower total porosity (43.00\%) may result in reduced crop yields. Under these conditions, in the experiment of Botta et al. (2016) with soybean crop, there was a reduction of 15.3; 21.0; and 22.1\% in production during 2010, 2011 and 2012 respectively, when the soil resistance went beyond $2.0 \mathrm{MPa}$ due to traffic action from a harvester. Traffic pressure during the first year was concentrated approximately between 7 and $22 \mathrm{~cm}$, also found by Trentin (2015) in his studies. During the second year, the PR reduced $54.4 \%$ (Figure 2), with overall oscillation from 0.4 to $1.9 \mathrm{MPa}$, except for few small areas, spots of 2.2 to $2.5 \mathrm{MPa}$, probably from some action of the grips from tires of harvesters.

When comparing the managements, there was a reduction in resistance when adding the shank at $12 \mathrm{~cm}$; however, as the values found here are not restrictive, there will be no impediment to root development in relation to soil resistance. When comparing the years, there was an improvement in the data, fact probably linked to the temporal action of the treatments, since the no-till farming management system recommends crop rotation among other things. Table 3 demonstrates that the amount of Raphanus raphanistrum emerged was much higher during the second year, with the said fact responsible for improving the soil physical state under NTS in the studies of Guedes Filho et al. (2013).

Regarding weed dynamics, the main occurrences in both crops were Digitaria horizontalis (crabgrass), Raphanus raphanistrum (turnip) and Ipomoea grandifolia (little bell). Digitaria horizontalis in the $2017 / 18$ crop (Table 3) demonstrated higher densities in the rolled straw management. In chopped or rolled straw managements, there may be spaces without any or with less coverage that allowed this weed development, as this species is photoblastic positive and needs light to begin its germination process (Barroso et al., 2019).

During the 2015/16 crop, there were also larger amounts of Digitaria horizontalis in the row compared to the inter-row. In the first one, there was less straw and more disturbance by the fertilizer shank. Soil mobilization, regardless of the method, promotes greater weed density, indicating a greater care in additional control prior to sowing in order to avoid reduced yield caused by weeds (Nagahama et al., 2014). Regarding the species Raphanus raphanistrum, in the 2015/16 crop, the highest density also occurred in the chopped straw, which was not repeated in the following year, where the straw management had no effect on the occurrence of this species.

Total density of weeds and the species Ipomoea grandifolia and Digitaria horizontalis showed interaction between straw management with the occurrence location (row or inter-row) (Table 4) in 2015/2016. Chopped straw management affected more intensely the Digitaria horizontalis, thus resulting in larger amounts of the species. In other straw managements, there was a reduction of more than $50 \%$ in the inter-row, which again demonstrates the inverting action of the fertilizer shank. One of the factors responsible for increasing the density and number of emerged species is the soil disturbance provoked by the shank (Nagahama et al., 2014).

The highest density of Ipomoea grandifolia occurred in the inter-row, except in chopped straw. Occurring simultaneously

Table 3. Total weed density (plant $\mathrm{m}^{-2}$ ) in the different straw managements, action depths of the seeder shank, in the row and inter-row of the soybean crop during 2015/2016 and 2017/2018 and F test.

\begin{tabular}{|c|c|c|c|c|c|c|c|c|}
\hline \multirow{2}{*}{$\begin{array}{c}\text { Year/Straw } \\
\text { management (SM) }\end{array}$} & \multicolumn{4}{|c|}{$2015 / 2016$} & \multicolumn{4}{|c|}{$2017 / 2018$} \\
\hline & $\begin{array}{c}\text { Digitaria } \\
\text { horizontalis }\end{array}$ & $\begin{array}{c}\text { Raphanus } \\
\text { raphanistrum }\end{array}$ & $\begin{array}{c}\text { Ipomoea } \\
\text { grandifolia }\end{array}$ & Total & $\begin{array}{c}\text { Digitaria } \\
\text { horizontalis }\end{array}$ & $\begin{array}{c}\text { Raphanus } \\
\text { raphanistrum }\end{array}$ & $\begin{array}{c}\text { Ipomoea } \\
\text { grandifolia }\end{array}$ & Total \\
\hline Chopped & $--^{2}$ & $2.75 a^{1}$ & $--^{2}$ & $113.49 \mathrm{a}$ & $77.04 \mathrm{~b}$ & $163.04 \mathrm{a}$ & $9.10 \mathrm{a}$ & $306.80 a$ \\
\hline Rolled & -- & $0.76 \mathrm{~b}$ & -- & $71.56 b$ & $221.23 a$ & $208.61 \mathrm{a}$ & $4.11 \mathrm{a}$ & $485.97 \mathrm{a}$ \\
\hline Natural & -- & $0.31 \mathrm{~b}$ & -- & $70.91 b$ & $160.61 \mathrm{ab}$ & $145.81 \mathrm{a}$ & $5.71 \mathrm{a}$ & $350.3 \mathrm{a}$ \\
\hline \multicolumn{9}{|l|}{ Shank depth (D) } \\
\hline NTS73 & $18.88 \mathrm{a}$ & $1.72 \mathrm{a}$ & $0.59 a$ & $81.44 \mathrm{a}$ & $177.85 \mathrm{a}$ & $211.82 \mathrm{a}$ & $6.38 a$ & $445.49 a$ \\
\hline NTS12 & $22.46 \mathrm{a}$ & $0.83 a$ & $2.42 \mathrm{~b}$ & $89.20 \mathrm{a}$ & $128.07 \mathrm{a}$ & $133.16 \mathrm{a}$ & $6.24 \mathrm{a}$ & $316.55 a$ \\
\hline \multicolumn{9}{|l|}{ Location (L) } \\
\hline Row & $--^{2}$ & $1.56 \mathrm{a}$ & $--^{2}$ & $87.91 \mathrm{a}$ & $140.26 a$ & $167.60 \mathrm{a}$ & $4.68 \mathrm{a}$ & 342.6 a \\
\hline Inter-row & -- & $0.99 \mathrm{a}$ & -- & $82.73 \mathrm{a}$ & $165.67 \mathrm{a}$ & $177.38 \mathrm{a}$ & $7.93 \mathrm{a}$ & $419.44 \mathrm{a}$ \\
\hline \multicolumn{9}{|l|}{ F factor } \\
\hline SM & $*$ & $*$ & $*$ & $*$ & $*$ & $*$ & ns & ns \\
\hline D & ns & ns & $*$ & ns & ns & ns & ns & ns \\
\hline $\mathrm{L}$ & $*$ & ns & ns & ns & ns & ns & ns & ns \\
\hline$S M \times D$ & ns & ns & ns & ns & ns & ns & ns & ns \\
\hline$S M \times D$ & $*$ & ns & $*$ & $*$ & ns & ns & ns & ns \\
\hline$D \times L$ & ns & ns & ns & ns & ns & ns & ns & $*$ \\
\hline$S M \times D \times L$ & ns & ns & ns & ns & ns & ns & ns & ns \\
\hline CV\% & 23.27 & 42.85 & 36.47 & 10.77 & 42.70 & 42.70 & 58.65 & 35.12 \\
\hline
\end{tabular}

${ }^{1}$ Means followed by the same letter did not differ from each other by Tukey test at $5 \%(*)$ of probability. ns: not significant; CV: coefficient of variation;

2 Means and comparison test for the main effects "Straw Management" and "Locations" are not presented for the species $D$. horizontalis and $I$. grandifolia, since the interaction between these two factors is displayed in Table 4.

${ }^{3}$ NTS7: No-till system with fertilizer shank acting at $7 \mathrm{~cm}$; NTS12: No-till system with fertilizer shank acting at $12 \mathrm{~cm}$. 
Table 4. Density (plants $\mathrm{m}^{-2}$ ) of Digitaria horizontalis, Ipomoea grandifolia and total in the interaction between straw management with the position in the row and inter-row of the soybean crop in 2015/2016.

\begin{tabular}{|c|c|c|c|c|c|c|}
\hline \multirow{2}{*}{$\begin{array}{c}\text { Straw } \\
\text { management (SM) }\end{array}$} & \multicolumn{2}{|c|}{ Digitaria horizontalis } & \multicolumn{2}{|c|}{ Ipomoea grandifolia } & \multicolumn{2}{|c|}{ Total } \\
\hline & Row & Inter-row & Row & Inter-row & Row & Inter-row \\
\hline Chopped & $27.81 \mathrm{aA}^{*}$ & $29.76 \mathrm{aA}$ & $1.25 \mathrm{aB}$ & $5.35 \mathrm{aA}$ & $104.37 \mathrm{aA}$ & $122.61 \mathrm{aA}$ \\
\hline Rolled & $22.65 \mathrm{aA}$ & $10.71 \mathrm{bB}$ & $0.46 \mathrm{aA}$ & $1.19 \mathrm{bA}$ & $77.65 \mathrm{bA}$ & $65.47 \mathrm{bA}$ \\
\hline Natural & $22.96 \mathrm{aA}$ & $10.11 \mathrm{bB}$ & $0.78 \mathrm{aA}$ & $0 \mathrm{bA}$ & $81.71 \mathrm{abA}$ & $60.11 \mathrm{bB}$ \\
\hline CV \% & \multicolumn{2}{|c|}{23.27} & \multicolumn{2}{|c|}{36.47} & \multicolumn{2}{|c|}{10.77} \\
\hline
\end{tabular}

*Means followed by the same uppercase letter in the row, or lowercase in the column, did not differ from each other by the Tukey test ( $p \geq 0.05$ ). CV - Coefficient of variation.

with the spreading of straw, the chopping action does not affect this weed or Digitaria horizontalis in terms of location in the row or inter-row. Allied to this, I. grandifolia is not responsive to the greater or lesser soil disturbance at the different seeder shank action depths. In this species, the straw is not efficient in its suppression as the seeds are photoblastic negative (Barroso et al., 2019).

Total weed density was higher under the chopped straw management in the inter-row, thus differing from the other managements, which had a reduction of 46.6 and $49 \%$ respective to rolled and natural straws. As mentioned beforehand, there may be spaces between the straw particles in the chopped treatment, thus favoring the solar luminosity into the soil. When comparing unrolled and rolled straw in the longitudinal direction, weed dry weight increased from 427.25 to $1559.27 \mathrm{~g} \mathrm{~m}^{-2}$, respectively (Santos et al., 2020). Changing the rotation of the razor drive mechanism from $2200 \mathrm{rpm}$ to $1600 \mathrm{rpm}$ resulted in weed dry weight of 125.8 and $240.1 \mathrm{~g} / 0.25 \mathrm{~m}^{2}$, respectively (Brighenti et al., 2011).

Total weed density was significant during the 2017/18 crop in the interaction between furrowing depth and location, row or inter-row (Table 5). This was lower under the NTS12 management in the row position, with the inter-row having an increase of $131.4 \%$ in this treatment. This demonstrates that the hypothesis of a greater rolling by the furrowing element in the sowing row, aiming at physical improvement, will not result in increased weed density.

The soybean crop yield (Table 6) demonstrated interaction between the factors of straw management and action depth of the seeder shank during the first season only, for isolated factors there was influence of straw management in this same season. In the chopped and natural straw cover condition, the highest yields occurred during the first year, differing from the rolled straw condition. This yield reduction in the area

Table 5. Total density of emerged weeds (plant $\mathrm{m}^{-2}$ ) according to the interaction between the action depths of the seeder shank and the weed occurrence in the row or inter-row of the crop during the 2017/18 season.

\begin{tabular}{ccc}
\hline \multirow{2}{*}{ Shank depth } & \multicolumn{3}{c}{ Location } \\
\cline { 2 - 3 } & Row & Inter-row \\
\hline NTS7 & $494.16 \mathrm{aA}^{*}$ & $396.82 \mathrm{aA}$ \\
NTS12 & $191.04 \mathrm{bB}$ & $442.06 \mathrm{aA}$ \\
CV \% & \multicolumn{3}{c}{35.12} \\
\hline
\end{tabular}

* Means followed by the same uppercase letter in the row, or lowercase in the column, did not statistically differ from each other by the $F$ test $(p \geq 0.05)$.

${ }^{1} \mathrm{NTS7}$ : No-till system with furrower acting at $7 \mathrm{~cm}$; NTS12: No-till system furrower acting at $12 \mathrm{~cm}$
Table 6. Soybean yield $\left(\mathrm{kg} \mathrm{ha}^{-1}\right)$ during the $2015 / 2016$ and 2017/2018 seasons under different straw managements and fertilizer shank depths, and $F$ test.

\begin{tabular}{lcc}
\hline \multirow{2}{*}{ Straw } & \multicolumn{2}{c}{ Year } \\
\cline { 2 - 3 } management (SM) & $\mathbf{2 0 1 5 / 2 0 1 6}$ & $\mathbf{2 0 1 7 / 2 0 1 8}$ \\
\hline Chopped & $4342.24 \mathrm{~b}^{*}$ & $3919.24 \mathrm{a}$ \\
Rolled & $3879.34 \mathrm{a}$ & $3826.74 \mathrm{a}$ \\
Natural & $4421.97 \mathrm{~b}$ & $3991.33 \mathrm{a}$ \\
\hline Shank depth (D) & & \\
NTS7 & $4158.12 \mathrm{a}$ & $3842.05 \mathrm{a}$ \\
NTS12 & $4270.93 \mathrm{a}$ & $3982.83 \mathrm{a}$ \\
\hline F test & & \\
SM & $*$ & $\mathrm{~ns}$ \\
D & $\mathrm{ns}$ & $\mathrm{ns}$ \\
SM x D & $*$ & $\mathrm{~ns}$ \\
CV (\%) & 5.95 & 15.73 \\
\hline
\end{tabular}

*Means followed by the same letter in the straw management and in the furrowing depth do not differ statistically from each other, by the Tukey and $F$ tests ( $p \geq 0.05$ ) respectively; $\mathrm{CV}=$ coefficient of variation

${ }^{1}$ NTS7: No-till system with fertilizer shank acting at $7 \mathrm{~cm}$; NTS12: No-till system with fertilizer shank acting at $12 \mathrm{~cm}$

with rolled straw should be related to the soil physical state, which had a high soil area with resistance above $2.5 \mathrm{MPa}$ (Figure 1C, D). In areas with low weed incidence, Silva et al. (2016) mention that straw management does not influence the crop yield, only the cover decomposition speed and seed distribution in the soil. This disagrees with the data found in this study, probably due to the soil physical conditions that here show restrictive effects on plant development.

In the condition that the soil is, we verified that physical action did not influence yield, although there was a reduction in soil strength (Figure 1) and SD (Table 1) during the first year, and a TP increase (Table 1) during the second, which points to physical improvements; yet these were not enough to increase yield. However, using furrowers during the soybean sowing operation in the state of Paraná minimized the soil compaction effects and consequently attained higher yields (Trentin, 2015).

The interaction of straw management with the furrower depth was significant only in the first year (Table 6); this difference shown in Figure 3, in which the rolled straw had the lowest yield, differing from the other managements, which also occurred in both furrowing depths. This situation, as aforementioned, is linked to the soil physical condition (Figure 1C, D), as this treatment was the one that demonstrated the lowest weed density (Table 3 and 4); in other words, there was no weed competition in the soybean crop for this treatment. 


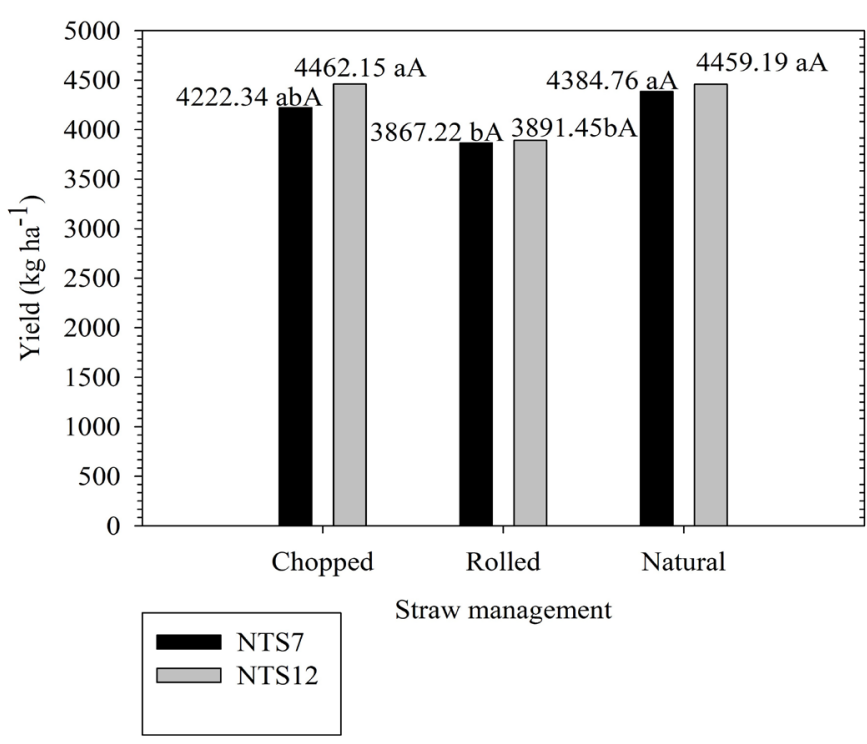

* Means followed by the same lowercase (comparing stra management) or uppercase letters (comparing between furrowing depths) do not differ statistically from each other by the Tukey and $F$ tests $(p \geq 0.05)$, respectively

Figure 3. Soybean crop yield at the different straw managements and seeder shank depths during the 2015/2016 seasons.

\section{Conclusion}

Straw cover management associated with the action depth of the fertilizer shank during sowing influenced weed emergence, with a tendency for greater populations under the conditions of chopped or rolled straws.

Increasing the shank depth reduces the soil mechanical resistance to penetration and the bulk density, and increases the total porosity, thus serving as a technique to improve the soil physical state in the no-till farming system.

\section{Compliance with Ethical Standards}

Funding: This work has no financial funding.

Conflict of interest: The authors declare no conflict of interest.

Author contribution: Conceptualization: DPR, ALN, AA; Data curation: DPR, ALN, AA, ML; Formal analysis: DPR, ALN; Funding acquisition: No foundation features were used; Investigation: DPR, AA, ML; Methodology: DPR, AA, ML; Project administration: DPR; Resources: DPR, AA, ML; Software: No programs were developed; Supervision: DPR; Validation: DPR, ALN; Visualization: DPR; Writing - original draft: DPR, ALN, AA, ML; Writing - review \& editing: DPR, ALN.

\section{Literature Cited}

Banzato, D. A.; Kronka, S. N. Experimentação agrícola. 4.ed. Jaboticabal: FUNEP, 2006. 237p.

Barroso, A.A.M.; Ferreira, P.S.H.; Martins, D. Growth and development of Ipomoea weeds. Planta Daninha, v. 37, n. 1, p.1-9, 2019. https://doi.org/10.1590/s0100-83582019370100034.
Botta, G.F.; Tolón-Becerra, A.; Rivero, D.; Laureda, D.; Ramírez-Roman, M.; Lastra-Bravo, X.; Agnes, D.; Flores-Parra, I.M.; Pelizzari, F.; Martiren, $\mathrm{V}$. Compactión produced by combine harvest traffic: Effect on soil and soybean (Glycine $\max$ l.) yields under direct sowing in Argentine an Pampas. European Journal of Agronomy, v. 74, p. 155-163, 2016. https://doi.org/10.1016/j.eja.2015.12.011.

Brighenti, A.M.; Oliveira, M.F.; Coutinho Filho, S. de A. Controle de plantas daninhas por roçada articulada e eletrocussão. In: Oliveira Junior, R.S.; Constatin, J.; Inoue, M.H. (Eds.). Biologia e manejo de plantas daninhas. 1.ed. Curitiba: Omnipax; 2011. p.1-36.

Calonego, J. C.; Raphael, J. P. A.; Rigon, J. P. G.; Oliveira Neto, L. de; Rosolem, C. A. Soil compaction management and soybean yields with cover crops under no-till and occasional chiseling. European Journal of Agronomy, v.85, p.31-37, 2017. https://doi. org/10.1016/j.eja.2017.02.001.

Castioni, G.A.F.; Cherubin, M.R.; Bordonal, R. de O.; Barbosa, L.C.; Menandro, L.M.S.; Carvalho, J.L.N. Straw removal affects soil physical quality and sugarcane yield in Brazil. BioEnergy Research, v. 12 , n. 1, p. 1-12, 2019. https://doi.org/10.1007/s12155-01910000-1.

Cherubin, M.R.; Eitelwein, M.T.; Fabbris, C.; Weirich, S.W.; Silva, R.F. da; Silva, V.R. da; Basso, C.J. Qualidade física, química e biológica de um latossolo com diferentes manejos e fertilizantes. Revista Brasileira de Ciência do Solo, v. 39, n. 2, p. 615-625, 2015. https://doi.org/10.1590/01000683rbcs20140462.

Drescher, M.S.; Reinert, D.J.; Denardin, J.E.; Gubiani, P.I.; Faganello, A.; Drescher, G.L. Duração das alterações em propriedades físico-hídricas de Latossolo argiloso decorrentes da escarificação mecânica. Pesquisa Agropecuária Brasileira, v. 51, n. 2, p. 159168, 2016. https://doi.org/10.1590/S0100-204X2016000200008.

Drescher, M.S.; Reinert, D.J.; Denardin, J.E.; Gubiani, P.I.; Faganello, A.; Silva, B.R. da; Zardin, M.C. fertilizer shanks to promote soil decompaction in the seeding operation. Ciência Rural, v. 47, n. 3, p. 1-8, 2017. https://doi.org/10.1590/0103-8478cr20160026.

Empresa Brasileira de Pesquisa Agropecuária - Embrapa. Manual de métodos de análise de solo. 3.ed. Brasília: Embrapa, 2017. 575p.

Empresa Brasileira de Pesquisa Agropecuária - Embrapa. Sistema brasileiro de classificação de solos. 5.ed. Brasília: Embrapa, 2018. $780 p$.

Favarato, L.F.; Galvão, J.C.C.; Souza, J.L.; Guarçoni, R.C.; Souza, C.M.; Cunha, D.N. Population density and weed infestation in organic no-tillage corn cropping system under different soil covers. Planta Daninha, v. 32, n. 4, p. 739-746, 2014. https://doi.org/10.1590/ S0100-83582014000400008

Guedes Filho, O.; Silva, A.P. da; Giarola, N. F. B.; Tormena, C.A. Structural properties of the soil seedbed submitted to mechanical and biological chiseling under no-tillage. Geoderma, v. 204-205, p. 94-101, 2013. https://doi.org/10.1016/j. geoderma.2013.04.017.

Karayel, D.; Šarauskis, E. Environmental impact of no-tillage farming. Journal of Environmental Research, v. 75, n. 1, p. 7-12, 2019. https://doi.org/10.5755/j01.erem.75.1.20861.

Milagres, R.S., Machado, T. de A.; Vieira, L.B.; Fernandes, H.C. Avaliação dos atributos físicos do solo em áreas inclinadas com sistema de plantio direto. Revista Ciência Agrícola, v. 16, n. 3, p. 557-63, 2018. https://doi.org/10.28998/rca.v16i3.4203. 
Nagahama, H.J.; Cortez, J.W.; Concenço, G.; Araujo, V.F.; Honorato, A.C. Dinâmica e variabilidade espacial de plantas daninhas em sistemas de mobilização do solo em sorgo forrageiro, Planta Daninha, v. 32, n. 2, p. 265-274, 2014 https://doi.org/10.1590/ S0100-83582014000200003.

Qiu, Y.; Wang, W. Effects of tillage patterns on soil moisture and soybean yield in sloping fields. Transactions of the Chinese Society of Agricultural Engineering, v. 34, n. 3, p. 128-137, 2018. https://doi.org/10.1016/S2095-6339(15)30030-7.

Reichert, J.M.; Suzuki, L.E.A.S.; Reinert, D.J. Compactação do solo em sistema agropecuários e florestais: identificação, efeitos, limites críticos e mitigação. In: Ceretta, C.A.; Silva, L.S.; Reichert, J.M. (Orgs.). Tópicos em ciência do solo. Viçosa: Sociedade Brasileira de Ciência do Solo, 2008. v. 5, p. 49-134.

Rosa, D.P. da; Pesini, F.; Pagnussat, L.; Fincatto, D. Guilhotina ou subsolagem? Cultivar máquinas, v.151, p 10-12, 2015. https:// issuu.com/grupocultivar/docs/maquinas_151. 22 Jun. 2019.
Santos, J.F. dos; Nogara, W.J.P.; Cortez, M.G.; Ohse, S. Manejo da palha da aveia preta sobre a cultura da soja em semeadura direta. Visão Acadêmica, v.20, n. 4, p. 45-61, 2019. https://doi. org/10.5380/acd.v20i4.69695.

Silva, A.C.; Queiroz, J.R.G.; Martins, C.C.; Pereira, M.R.R.; Martins, D. Emergência de espécies de plantas daninhas do gênero Brachiaria sob palha de cana-de-açúcar. Planta Daninha, v. 34, n. 3, p. 423432, 2016. https://doi.org/10.1590/s0100-83582016340300003.

Sivarajan, S.; Maharlooei, m.; Bajwa, S.G.; Nowatzki, J. Impact of soil compaction due to wheel traffic on corn and soybean growth, development and yield. Soil and Tillage Research, v. 175, n. 1, p. 234-43, 2018. https://doi.org/10.1016/j.still.2017.09.001.

Trentin, R.G. Desempenho de sulcadores no desenvolvimento e produtividade da soja em solo submetido a diferentes níveis de compactação. Paraná: Universidade Tecnológica Federal do Paraná, 2015. 98p. Tese Doutorado. http://repositorio.utfpr.edu. br/jspui/handle/1/1612. 22 Jun. 2019. 